\title{
Foliar Applications of Urea Affect Nitrogen Reserves and Cold Acclimation of Sweet Cherries (Prunus avium L.) on Dwarfing Rootstocks
}

\author{
Theoharis Ouzounis and Gregory A. Lang ${ }^{1}$ \\ Department of Horticulture, Michigan State University, A388D Plant and \\ Soil Sciences, East Lansing, 48824
}

Additional index words. nutrient storage, remobilization, flower spurs, spring growth, Prunus cerasus, Prunus canescens, Gisela ${ }^{\circledR}$

\begin{abstract}
Seasonal uptake, storage, and remobilization of nitrogen (N) are of critical importance for plant growth. The use of $\mathbf{N}$ reserves for new growth in the spring is especially important for sweet cherry (Prunus avium $\mathrm{L}$.), for which new shoot and fruit growth is concomitant and fruit development occurs during a relatively short bloom-toripening period. Sweet cherries grafted on precocious, dwarfing rootstocks such as the interspecific ( $P$. cerasus $\times P$. canescens) hybrids Gisela ${ }^{\circledR} 5$ and 6 tend to produce large crops but smaller fruit when crop load is not balanced with adequate leaf area. Study objectives were to: 1 ) characterize natural $N$ remobilization during fall and winter to canopy reproductive and vegetative meristems; 2 ) determine the effect of fall foliar urea applications on storage $\mathrm{N}$ levels in flowering spurs; 3 ) determine whether differential storage $\mathbf{N}$ levels influence spur leaf formation in spring; and 4) determine whether fall foliar urea applications affect the development of cold-hardiness. During fall, total $N$ in leaves decreased by up to $51 \%$ [dry weight (DW)] and increased in canopy organs such as flower spurs by up to $27 \%$ (DW). The $\mathrm{N}$ concentration in flower spurs increased further in spring by up to $150 \%$ (DW). Fall foliar applications of urea increased storage $\mathrm{N}$ levels in flowering spurs (up to $40 \%$ ), shoot tips (up to $20 \%$ ), and bark (up to 29\%). Premature defoliation decreased storage $\mathrm{N}$ in these tissues by up to $30 \%$. Spur leaf size in the spring was associated with storage $\mathrm{N}$ levels; fall foliar urea treatments increased spur leaf area by up to $24 \%$. Foliar urea applications increased flower spur $N$ levels most when applied in late summer to early fall. Such applications also affected the development of cold acclimation in cherry shoots positively during fall; those treated with urea were up to $4.25{ }^{\circ} \mathrm{C}$ more cold-hardy than those on untreated trees.
\end{abstract}

Nitrogen is the most important element for maintaining growth and high productivity in tree fruits (Titus and Kang, 1982). Sweet cherries (Prunus avium L.) on precocious, interspecific $(P$. cerasus $\times P$. canescens $)$ Gisela $^{\circledR}$ (Gi) rootstocks (e.g., Gi3, Gi5, Gi6, Gi12) are likely to produce large crops but small-sized fruit when total leaf area is not adequate to support such crop loads (Andersen et al., 1999; Lang, 2000; Whiting and Lang, 2004). When root uptake of $\mathrm{N}$ is limited in early spring by cold soils and low canopy transpiration rates (Zavalloni, 2004), the restricted availability of $\mathrm{N}$ for growth may contribute to unfavorable leaf area-to-fruit ratios.

\footnotetext{
Received for publication 5 Jan. 2011. Accepted for publication 8 May 2011.

We gratefully acknowledge the International Fruit Tree Association (IFTA) and the Michigan Agricultural Experiment Station for financial support of this work and a graduate research assistantship for T. Ouzounis, respectively. We also gratefully acknowledge intellectual input and consultative guidance from colleagues Eric Hanson, David Rothstein, Jim Flore, and Lynn Sage during the course of this project.

${ }^{1}$ To whom reprint requests should be addressed; e-maillangg@msu.edu.
}

Nitrogen supply affects leaf, bud, and fruit development. Early-season growth in trees during spring is supported by remobilization of stored N, so they do not depend wholly on $\mathrm{N}$ supplied by current-year root uptake (Millard, 1996). Zavalloni (2004) found that sweet cherries absorbed little soil $\mathrm{N}$ before budbreak, even up to 3 to 4 weeks after budbreak; therefore, storage $\mathrm{N}$ is critical for supplying initial spring growth. Ayala and Lang (2004, 2008) have shown that spur leaves supply the majority of the photosynthetic carbon for cherry fruit growth, and their development and expansion are limited to the first 3 to 4 weeks after budbreak, coinciding with the supply of $\mathrm{N}$ from remobilized storage reserves. Sweet cherry flowering occurs before full expansion of leaves; consequently, the early stages of flowering and fruiting as well as initial vegetative growth depend on the storage reserves from the previous season (Keller and Loescher, 1989; McCammant, 1988). Other deciduous trees, like apples (Malus domestica Borkh.), also are dependent primarily on storage reserves for spur leaf formation; however, because apple spur leaves begin expanding before anthesis (thus establishing an evapotranspirational flow within the tree), $\mathrm{N}$ uptake by roots begins at approximately full bloom
(Neilsen et al., 1997). Consequently, from bloom to fruit set or early fruit development, apple fruit draw on $\mathrm{N}$ sources from both reserves and root uptake, whereas cherries draw primarily on $\mathrm{N}$ reserves during this period. The fruit development period in apple also is longer than in cherry, meaning a greater proportion of fruit development occurs during active current-season carbon and $\mathrm{N}$ uptake.

Foliar applications of urea in fall have had positive effects in deciduous fruit trees (e.g., Titus and Kang, 1982). Urea is the most widely used form of $\mathrm{N}$ for foliar applications because of its rapid absorption, low phytotoxicity, and high solubility (Bondada et al., 2001; Yamada et al., 1965). Johnson et al. (2001) showed that $\mathrm{N}$ for normal growth of peach (Prunus persica Batsch.) buds, shoots, and roots can be supplied adequately by foliar urea applications during the growing season. Because sweet cherries bloom early and have a short fruit development period, a better understanding of storage $\mathrm{N}$, and its manipulation and remobilization, may lead to better orchard management strategies for improving fruit quality on high-yielding, vigor-reducing rootstocks such as Gisela 5.

Little is know about the physiological relationship between nutrients and perennial plant cold tolerance mechanisms; practices that stimulate prolonged shoot growth in late summer such as soil-applied $\mathrm{N}$ can increase tissue susceptibility to damage by low temperatures in fall or winter. Some foliarapplied nutrients can help promote cold acclimation and stress resistance and/or enhance repair mechanisms after damage (Raese, 1996; Stover et al., 1999). In sweet cherry, the effect of fall foliar urea applications on plant susceptibility to freezing injury is unknown. Therefore, the objectives of this study were to: 1) characterize natural $\mathrm{N}$ remobilization from leaves to reproductive and vegetative meristems in sweet cherry during fall and winter; 2) determine the effect of fall foliar urea applications on storage $\mathrm{N}$ levels in flowering spurs; 3 ) determine whether differential storage $\mathrm{N}$ levels in spurs influence spur leaf formation in spring; and 4) determine whether fall foliar urea applications affect the development of cold-hardiness.

\section{Materials and Methods}

The following experiments were conducted at Michigan State University's Clarksville Horticultural Experiment Station (lat. $42.842^{\circ} \mathrm{N}$, long. $85.242^{\circ} \mathrm{W}$ ). All experimental trees had been subjected to standard cultural practices (i.e., dormant pruning, spring soil fertilization, timely pesticide applications) in the years before imposition of treatments.

Expt. 1. Nitrogen remobilization from leaves during fall senescence was characterized in 6-year-old 'Sandra Rose'/Gi5 and 'Rainier'/Gi5 sweet cherry trees. There were five single-tree replications per cultivar. In Fall 2005, 10 shoot leaves, 10 flowering spur leaves, and 10 flowering spurs with buds 
were sampled from each tree on 18,24 , and 28 Oct. (start of leaf color change) and on 1, 4 (start of leaf drop), and 8 Nov. The samples were placed in zip-lock bags in a cooler for transport from the farm to the laboratory; immediately on arrival, they were frozen and stored at $-60{ }^{\circ} \mathrm{C}$ for later analysis of total $\mathrm{N}$ (see subsequently). Leave abscission was completed by 21 Nov.

Expt. 2. The distribution and remobilization of $\mathrm{N}$ in selected sweet cherry canopy tissues (shoot leaves, spur leaves, and spur buds) was characterized from Fall 2006 to Spring 2007. There were five single-tree replications of 9-year-old 'Hedelfinger'/ Gi5 sweet cherry trees. Ten flower spurs were sampled from each tree on 26 Oct., 2 and 9 Nov., and 9 Dec. of 2006 as well as on 9 Jan., 9 Feb., 9 Mar., 9 Apr., and 28 Apr. of 2007. Samples were transported, frozen, and stored for later analysis of total $\mathrm{N}$ as described previously.

Expt. 3. The potential to manipulate $\mathrm{N}$ reserves in selected overwintering canopy tissues, and their potential effects on subsequent spur leaf formation, was examined in 8-year-old 'Hedelfinger'/Gi5 sweet cherry trees. Five treatments were imposed in Fall 2005: $\mathrm{C}=$ untreated control, $\mathrm{T} 1=$ complete manual defoliation on 11 Oct. (to simulate severe predation by Japanese beetles and/or leaf loss to cherry leaf spot, both of which can be common in Michigan without an adequate pest control regimen), $\mathrm{T} 2=\mathrm{a}$ single foliar urea application $(1 \times)$ delivered at 5\% (10 lb/ 25 gal or $4.5 \mathrm{~kg} / 95 \mathrm{~L}$, low biuret urea) on 7 Oct., T3 $=$ a double application $(2 \times)$ delivered as $5 \%$ urea on 7 Oct. $+4 \%$ urea $(8 \mathrm{lb} / 25$ gal or $3.6 \mathrm{~kg} / 95 \mathrm{~L}$ ) on 11 Oct., and T4 = a triple application $(3 \times)$ delivered as $5 \%$ urea on 7 Oct. $+4 \%$ urea on 11 Oct. $+3 \%$ urea $(6 \mathrm{lb} / 25$ gal or $2.7 \mathrm{~kg} / 95 \mathrm{~L}$ ) on 18 Oct. Foliar urea was applied during midafternoon by a handgun to the point of drip at a rate comparable to 250 gal/acre $\left(2340 \mathrm{~L} \cdot \mathrm{ha}^{-1}\right)$, with untreated guard trees between treatment trees and care taken to avoid drift. There were eight single-tree replications for each treatment except T1 (defoliation), for which there were four single-tree replications.

Samples from each tree included one bark disk ( $2 \mathrm{~cm}$ in diameter) from the trunk about midcanopy height, 10 apices ( $2 \mathrm{~cm}$ long) from medium vigor shoots, and 10 flowering spurs collected on 21 Nov. 2005 (post-leaf drop) and 31 Mar. 2006 (early bud swell). Samples were transported, frozen, and stored as described previously for later analysis of total N. From each treatment, all leaves from 10 random fruiting spurs per tree were collected the subsequent spring on 9 June 2006. The number of leaves per spur, the length (centimeters) of the largest spur leaf, and the total leaf area (square centimeters) per spur (measured with a LI-300 Area Meter; LI-COR, Lincoln, NE) were recorded. A total of 100 fruit per tree were sampled randomly on 3 July 2006 to determine average fruit weights.

Expt. 4. To determine whether fall foliar urea applications affect the progression of cold acclimation, 30 'Ulster'/Gisela 6 (Gi6) sweet cherry trees ( 9 years old) were selected for uniformity and were assigned treatments randomly with guard trees between treatments. There were six single-tree replications of five treatments: controls (no treatment) plus foliar applications of $3.5 \%$ urea ( $7 \mathrm{lbs}$ in $25 \mathrm{gal}$ or $3.2 \mathrm{~kg}$ in $102 \mathrm{~L}$ of water) at four treatment regime timings from late summer through fall (Table 1). A handgun was used to apply urea during midafternoon to the point of drip with care taken to avoid drift. During fall, 10 flowering spurs from 2-year-old shoots were harvested periodically from each tree, transported, frozen, and stored for later analysis of total $\mathrm{N}$ as described previously. Control samples were harvested on 31 Aug., 12 and 28 Sept., 12 Oct., and 12 Dec.; urea treatment samples were harvested just before the second application for each treatment (T1 on 8 Sept., T2 on 21 Sept., T3 on 6 Oct., and T4 on 20 Oct.) as well as on $12 \mathrm{Dec}$. (fully dormant, after leaf drop).

For each treatment, shoots were sampled for cold-hardiness evaluation at 1 and 3 weeks after the second urea application as well as after leaf drop in late fall. On each sampling date (Table 1), 24 current-year shoots were collected, 12 for the control and 12 for the urea treatment to be compared. Four $50-\mathrm{cm}$ shoots of the current year's growth were sampled per treatment, two each from the west and east sides of each tree. As a result of alternate-row insecticide spraying, the west sides $(-\mathrm{JB})$ of trees had good control of Japanese Beetle (Popillia japonica), whereas the east sides $(+\mathrm{JB})$ had poor coverage and increased foliar damage as a result of beetle feeding; thus, these were kept separate for initial analysis and potential identification of any confounding effects. Harvested shoots were placed in plastic bags and kept in the covered bed of a pick-up truck for transportation between the experiment station and the campus laboratory. They were stored overnight in a $4{ }^{\circ} \mathrm{C}$ cold room until preparation for controlled freezing tests the next day (see subsequently). Air temperatures at the research site during the sampling period were acquired from the MSU Enviro-weather climatic station $(<\mathrm{http}$ ://www. agweather.geo.msu.edu/mawn/>) located several hundred meters southwest of the research orchard.

Total nitrogen analysis. All samples were removed from the freezer and dried for at least $3 \mathrm{~d}$ in a drying oven (Blue M; Blue Electrical, Blue Island, IL) at $60{ }^{\circ} \mathrm{C}$. The dried samples were ground with a Wiley mill (40-mm mesh size) and stored in plastic-lidded boxes with a desiccant (anhydrous calcium sulfate) until

Table 1. Treatment and sampling dates of foliar urea treatments applied to 'Ulster'/Gi6 sweet cherry trees during Fall 2007.

\begin{tabular}{llcc}
\hline Treatments & Treatment dates & $\begin{array}{c}\text { Cold-hardiness sample dates } \\
\text { (current-season shoot growth) }\end{array}$ & $\begin{array}{c}\text { Tissue nitrogen sample } \\
\text { dates (flower spurs) }\end{array}$ \\
\hline C (control) & No urea & $\begin{array}{c}\text { 12 and 25 Sept.; 2, 9,17, 24, } \\
\text { and 30 Oct.; 13 Nov.; 12 Dec. }\end{array}$ & 30 Aug., 12 and 28 Sept.; \\
& & 12 Oct.; and 12 Dec. \\
T1 & 31 Aug. + 8 Sept. & 12 Sept., 2 Oct., and 12 Dec. & 8 Sept. and 12 Dec. \\
T2 & 14 Sept. + 21 Sept. & 25 Sept., 17 Oct., and 12 Dec. & 21 Sept. and 12 Dec. \\
T3 & 28 Sept. + 6 Oct. & 9 and 30 Oct., and 12 Dec. & 6 Oct. and 12 Dec. \\
T4 & 12 Oct. + 20 Oct. & 24 Oct., 13 Nov., and 12 Dec. & 20 Oct. and 12 Dec. \\
\hline
\end{tabular}

further preparation for Kjeldahl analysis (Bradstreet, 1965).

For each sample, $0.15 \mathrm{~g}$ of finely ground material was placed into a digestion tube, after which $7 \mathrm{~mL}$ of concentrated sulfuric acid was added. After gently swirling to mix, one digestion tablet (Kjeltab) was added to each tube. The tubes were placed into a preheated $\left(375^{\circ} \mathrm{C}\right)$ aluminum heating block for digestion for $2 \mathrm{~h}$ after clearing (disappearance) of carbon. The tubes were then removed from the heating block and allowed to cool for $\approx 10$ min. Deionized (DI) water (10 to $20 \mathrm{~mL}$ ) was added to the digestion tubes while still warm. A vortex mixer was used to dissolve any crystals present. Each tube was diluted to the $50-\mathrm{mL}$ mark with DI water and mixed and then the contents were stored in small bottles $(23 \mathrm{~mL})$ in a refrigerator at $4{ }^{\circ} \mathrm{C}$.

Colorimetric determination of ammonium content was made at $660 \mathrm{~nm}$ using a QuickChem 8500 (Lachat Instruments, Rapid City, SD). All samples and reagents were brought to room temperature, and the samples were poured into 5-mL plastic sampler cups, rinsdigest before filling. DI water was pumped through all the manifold tubing (lines) for 5 to $10 \mathrm{~min}$ before replacement with reagent lines. The stock reagents used were $\mathrm{NaOH}$ ( $130 \mathrm{~g}$ in $2 \mathrm{~L}$ of DI water), $\mathrm{KNaC}_{4} \mathrm{H}_{4} \mathrm{O}_{6} \cdot 4 \mathrm{H}_{2} \mathrm{O}(100 \mathrm{~g}$ in $2 \mathrm{~L}$ of DI water), buffer $\left(0.5 \mathrm{M} \mathrm{NaH}_{2} \mathrm{PO}_{4}\right)$, $\mathrm{H}_{2} \mathrm{SO}_{4}(7 \mathrm{~mL}), \mathrm{C}_{7} \mathrm{H}_{5} \mathrm{NaO}_{3}(300 \mathrm{~g}$ in $2 \mathrm{~L}$ of DI water), $\mathrm{Na}_{2}\left[\mathrm{Fe}(\mathrm{CN})_{5} \mathrm{NO}\right](0.6 \mathrm{~g}$ in $2 \mathrm{~L}$ of $\mathrm{DI}$ water), $\mathrm{NaOCl}(250 \mathrm{~mL})$, and sampler wash solution. The reagent lines were placed in their respective reagent bottles with the exception of the sodium salicylate line; when the reagents had been pumping for at least $5 \mathrm{~min}$, the salicylate line was placed in its reagent bottle and the system was allowed to equilibrate for 10 min before beginning sample analysis (AOAC Official Methods of Analysis, 1990; Bowman et al., 1988; Bradstreet, 1965; Cope, 1916). The total $\mathrm{N}$ data was expressed on a DW basis rather than absolute $\mathrm{N}$ content per organ.

Cold-hardiness analysis. The shoot samples were prepared according to the procedure described by Howell and Weiser (1970) and McKenzie and Weiser (1975). Shoots were cut into three sections (apical, middle, and basal). The apical and basal sections also were cut into two pieces. One piece per treatment was positioned vertically on masking tape (sticky side up) at 4-cm intervals. A total of four shoot pieces per replication were positioned on the masking tape, two representing $+\mathrm{JB}$ and two representing $-\mathrm{JB}$. Another length of tape on top secured the twigs. Four replications were prepared for each target temperature and ing each cup with a small amount of sample 
a control. Each strip was then centered on top of moistened gauze over aluminum foil strips with the basal end of each shoot piece at the lengthwise fold. A copper-constantan thermocouple was inserted into the apical-end pith of a central twig from each strip and secured by tape to the foil. The lower half of the foil was folded up to pocket the strips inside. The whole unit was then rolled into a loose bundle for the controlled freezes.

The freezer temperature was allowed to equilibrate at $0{ }^{\circ} \mathrm{C}$ for $1 \mathrm{~h}$ followed by an incremental temperature drop of $4.0^{\circ} \mathrm{C} \cdot \mathrm{h}^{-1}$ for the samples before $12 \mathrm{Dec}$. and $2.0^{\circ} \mathrm{C} \cdot \mathrm{h}^{-1}$ for the samples from 12 Dec. For the shoots sampled before 12 Dec., the stepwise freezer temperatures were $-3,-7,-11$, and $-15^{\circ} \mathrm{C}$; for the last sampling on $12 \mathrm{Dec}$., the temperatures were $-11,-13,-15,-17,-19$, and $-21{ }^{\circ} \mathrm{C}$. When each target temperature was reached, four bundles (replications) were removed from the freezer and placed in a $4{ }^{\circ} \mathrm{C}$ storage room to slowly thaw overnight. The next day, bundles were removed from the $4{ }^{\circ} \mathrm{C}$ storage room, unrolled, and placed in a $25^{\circ} \mathrm{C}$ (room temperature) humidity chamber. Damage was determined 4 to $7 \mathrm{~d}$ later by slicing the wood with a razor blade and rating the phloem/cambium/ xylem tissue for visual browning. Shoot pieces with less than $50 \%$ browning were considered to be alive and those with more than $50 \%$ browning were considered to be dead. The temperature that caused $50 \%$ death $\left(\mathrm{LT}_{50}\right)$ was calculated by the Spearman-Karber formula (Bittenbender and Howell, 1974):

$$
\mathrm{LT}_{50}=\mathrm{T}_{\mathrm{L}}-1 / 2 \mathrm{~d}+\left[\mathrm{d}\left(\sum \mathrm{i}\right) / \mathrm{n}\right]
$$

where $T_{L}=$ lethal temperature or temperature below which no twigs are alive, $d=$ temperature exposure intervals, $\Sigma \mathrm{i}=$ number of dead samples, and $\mathrm{n}=$ number of replications.

Statistical analysis. The data were analyzed using SAS software (SAS Institute Inc., Cary, NC). Analysis of variance was conducted with proc analysis of variance and mean separations by LSMEANS. For the urea and defoliation treatments, each treatment was paired with the control for statistical significance of total $\mathrm{N}$ content and effect on spring leaf and fruit development.

\section{Results}

Expt. 1. During fall, total $\mathrm{N}$ levels in shoot and spur leaves of both 'Sandra Rose' (Fig. 1A) and 'Rainier' (Fig. 1B) sweet cherries decreased significantly, most dramatically from the end of October onward. There was a concomitant increase in total $\mathrm{N}$ content in flower spurs from the beginning of October to the beginning of November (leaf drop). In 'Sandra Rose', the overall decrease in shoot and spur leaf $\mathrm{N}$ concentration during the sampling period was $39 \%$ and $49 \%$, respectively; the increase in flower spur bud $\mathrm{N}$ content was $27 \%$. In 'Rainier', the overall decrease in shoot and spur leaf $\mathrm{N}$ content was $36 \%$ and $51 \%$, respectively. 'Rainier' flower spur bud $\mathrm{N}$ content increased from mid-October through early
November, although the overall change from early October was not significant. Total $\mathrm{N}$ content decreased the most in spur leaves for both cultivars.
Expt. 2. Flower spur total $\mathrm{N}$ concentration did not change between leaf drop and bud swell (i.e., during the winter period) (Fig. 2). As bud swell and development began in late
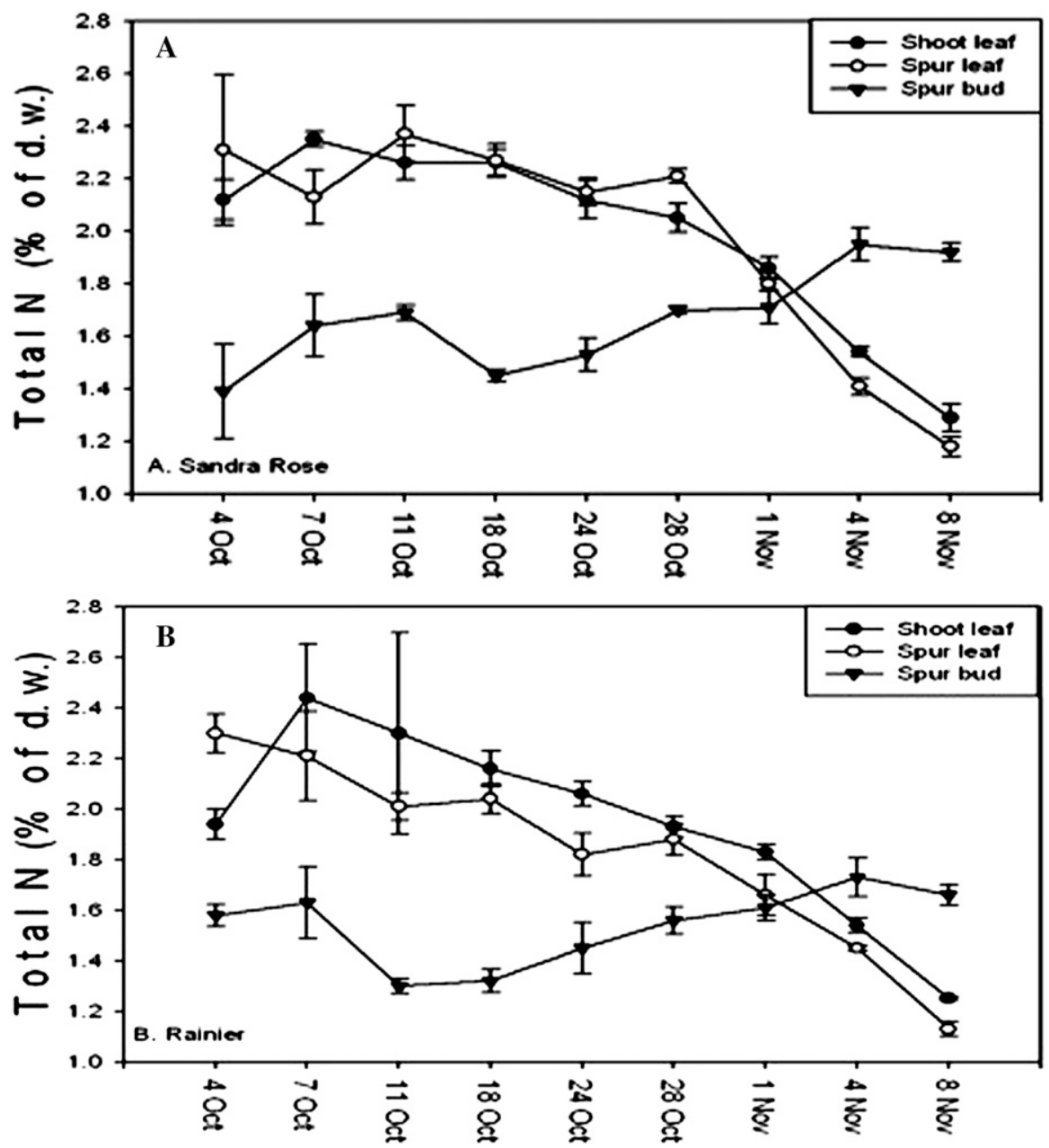

Fig. 1. Changes in total nitrogen content (dry weight basis) in 'Sandra Rose'/Gi5 (A) and 'Rainier'/Gi5 (B) sweet cherry shoot leaves, spur leaves, and flower spurs during Fall 2006. Data are means of five replications. Error bars are sEs from the mean.

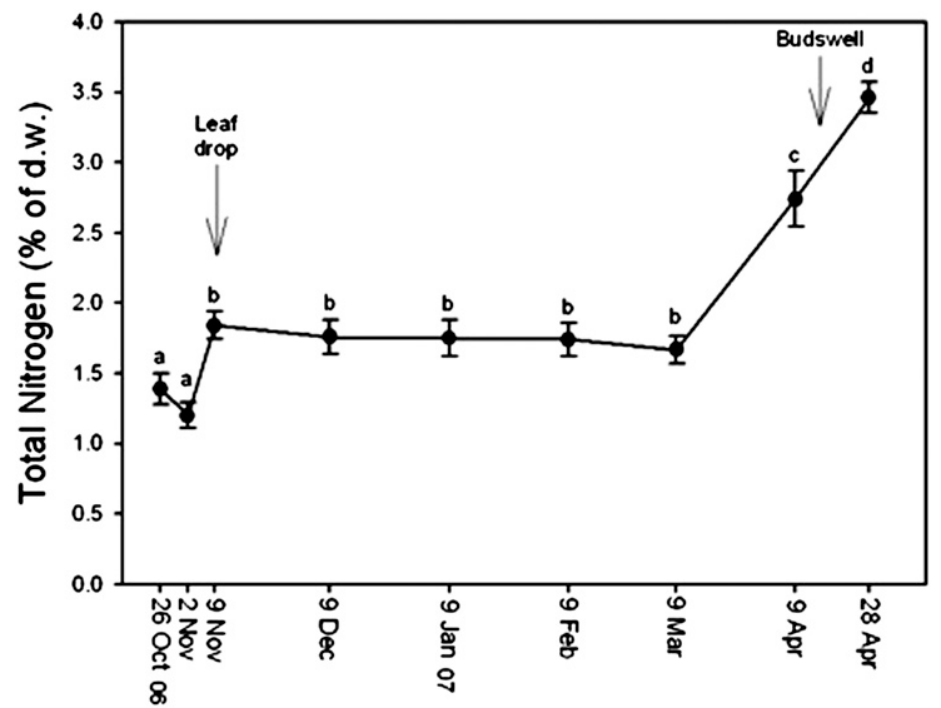

Fig. 2. Flowering spur nitrogen levels in 'Hedelfinger'/Gi5 sweet cherries from Fall 2006 to Spring 2007. Data presented are the averages of five replications. Error bars are SEs from the mean. Assignment of the same letter indicates values that are not significantly different. 
March and April, N content increased dramatically (up to $150 \%$ ) compared with $\mathrm{N}$ content during the winter.

Expt. 3. Total $\mathrm{N}$ levels tended to increase across all treatments and sampled tissues between late November (after leaf drop) and the end of March (beginning of bud swell) (Table 2). Total $\mathrm{N}$ levels were higher in flower spurs and shoot tips than in bark disks. When trees were defoliated prematurely (T1), the total $\mathrm{N}$ stored in the spur and shoot tissues in the fall was lower than in the controls, and these levels had not changed at the bud swell sampling in March, resulting in significantly lower values $(30 \%$ for spurs, $25 \%$ for shoot apices, and $21 \%$ for bark disks) than in the controls.

Fall applications of urea had no effect on total $\mathrm{N}$ levels in bark disks at either the November or the March sampling. The $1 \times$ (T2) and $2 \times$ (T3) urea applications did not significantly affect total $\mathrm{N}$ levels in shoot apices at either sampling time. Both of these treatments increased the total $\mathrm{N}$ values in the spurs in November, but only the value for the $1 \times$ application was significant, and neither was significantly different from the control by spring. However, the $3 \times(\mathrm{T} 4)$ application significantly increased total $\mathrm{N}$ values for spurs both in November (by $40 \%$ ) as well as in March (by 25\%). Shoot tip N content also was increased (by 20\%) in November, although this did not persist through March. Growth measurements during the subsequent spring found little difference between the treatments for leaf number per spur, although the $2 \times$ and $3 \times$ (T3 and T4) urea treatments were slightly but significantly higher compared with the control (Table 3). However, the leaf area per spur and size of the largest leaf per spur was influenced to a greater extent by treatment. Although the defoliation treatment did not differ from the control, the greatest leaf area per spur (24\% greater than the control) and the largest leaves (13\% to $15 \%$ larger than the control) occurred in T3 and T4, the highest rates of urea application. Fruit set and fruit size variability were high among trees in the orchard, resulting in no statistically significant differences between treatments.

Expt. 4. Although Japanese beetle damage was consistently greater on the east side of the tree canopies than the west, and plant tissues from each side subsequently were analyzed separately, no significant differences in total $\mathrm{N}$ levels nor in cold acclimation were found by canopy location within treatments (data not shown, see Ouzounis, 2008). The total N content in the untreated flower spurs increased from $0.6 \%$ at the end of August to $1.7 \%$ during early dormancy (12 Dec) (Fig. 3, solid line). The application of urea on 31 Aug. resulted in a spur total $\mathrm{N}$ content of $1.30 \%$ on 8 Sept., significantly higher than the control total $\mathrm{N}$ content of $0.65 \%$ on 12 Sept. When this early treatment was followed by a second application on 8 Sept., the dormant spur total $\mathrm{N}$ content during early winter (12 Dec.) remained significantly higher than the control $(2.2 \%$ versus $1.7 \%$; Table 4 ). A similar significant trend was found for the mid-September double

Table 2. Fall (2005) foliar urea and defoliation treatment effects on tissue total nitrogen (N) levels after leaf drop (dormant, 21 Nov. 2005) and before budbreak (bud swell, 31 Mar. 2006) in 'Hedelfinger'/Gi5 sweet cherries. $^{\text {z }}$



${ }^{\mathrm{z}} \mathrm{C}=$ control, $\mathrm{T} 1=$ defoliated on 11 Oct,; $\mathrm{T} 2=5 \%$ urea on 7 Oct.; $\mathrm{T} 3=5 \%$ urea on 7 Oct. $+4 \%$ urea on 11 Oct.; $\mathrm{T} 4=5 \%$ urea on 7 Oct. $+4 \%$ urea on 11 Oct. $+3 \%$ urea on 18 Oct.

Treatment values are significantly $(*)$ or not significantly (NS) different from the control at a $=0.05 ; \pm \%$ represents difference from $\mathrm{C}$.

Table 3. Fall foliar urea and defoliation treatment effects on subsequent season leaf (9 June 2006) and fruit (3 July 2006) parameters in 'Hedelfinger'/Gi5 sweet cherries.'

\begin{tabular}{lcccc}
\hline Treatments & $\begin{array}{c}\text { Leaves/spur } \\
(\text { no. })\end{array}$ & $\begin{array}{c}\text { Leaf area/spur } \\
\left(\mathrm{cm}^{2}\right)\end{array}$ & $\begin{array}{c}\text { Area of largest } \\
\text { leaf }\left(\mathrm{cm}^{2}\right)\end{array}$ & $\begin{array}{c}\text { Fruit } \\
\text { size }(\mathrm{g})\end{array}$ \\
\hline C (control) & 6.3 & 147 & 39 & 9.3 \\
T1 (defoliated) & $6.3 \mathrm{NS}$ & $153 \mathrm{NS}$ & $39 \mathrm{NS}$ & $8.2 \mathrm{NS}$ \\
T2 $(5 \%$ urea) & $6.5 \mathrm{NS}$ & $165^{*}$ & $42 \mathrm{NS}$ & $9.0 \mathrm{NS}$ \\
T3 $(5 \%+4 \%$ urea $)$ & $6.7^{*}$ & $183^{*}$ & $44^{*}$ & $8.7 \mathrm{NS}$ \\
T4 $(5 \%+4 \%+3 \%$ urea $)$ & $6.6^{*}$ & $183^{*}$ & $45^{*}$ & $8.9 \mathrm{NS}$ \\
\hline
\end{tabular}

${ }^{\mathrm{z}} \mathrm{C}=$ control; $\mathrm{T} 1=$ defoliated on 11 Oct.; $\mathrm{T} 2=5 \%$ urea on 7 Oct.; $\mathrm{T} 3=5 \%$ urea on 7 Oct. $+4 \%$ urea on 11 Oct.; $\mathrm{T} 4=5 \%$ urea on 7 Oct. $+4 \%$ urea on 11 Oct. $+3 \%$ urea on 18 Oct.

Treatment values are significantly $(*)$ or not significantly (NS) different from the control at a $=0.05$.

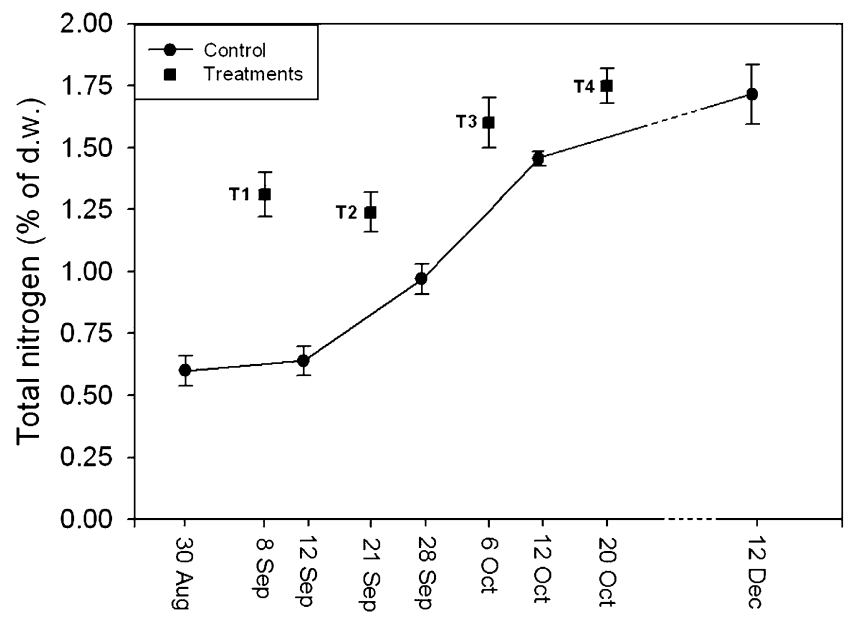

Fig. 3. Natural remobilization of nitrogen (solid line) into 'Ulster'/Gi6 sweet cherry flower spurs during Fall 2007 and effect of foliar urea (3.5\%) applications (squares) on 31 Aug. (T1, sampled on 8 Sept.), on 14 Sep (T2, sampled on 21 Sept.), on 28 Sep (T3, sampled on 6 Oct.), and on 12 Oct. (T4, sampled on 20 Oct.). Each treatment was sampled just before the planned second application (for the subsequent cold acclimation analyses). Error bars are ses from the mean.

urea treatment: the application on 12 Sept. resulted in a spur total $\mathrm{N}$ content of $1.23 \%$ on 21 Sept., significantly higher than the control total $\mathrm{N}$ content of $0.95 \%$ on 28 Sept. When this mid-September treatment was followed by a second treatment 1 week later, the dormant spur total $\mathrm{N}$ content during early winter (12 Dec.) remained significantly higher (at $2.1 \%$ ) than the control. The later double applications (T3 and T4) had initial, but lesser, positive effects on spur total $\mathrm{N}$ content, but these differences did not persist through to early winter (Fig. 3; Table 4).

Cold acclimation, as estimated by $\mathrm{LT}_{50}$ values, of untreated 'Ulster' sweet cherry shoots increased from a moderately hardy condition $\left(\mathrm{LT}_{50}=-9^{\circ} \mathrm{C}\right)$ in early September to approximately a $7^{\circ} \mathrm{C}$ more hardy condition $\left(-16^{\circ} \mathrm{C}\right.$ ) by early December (Fig. 4, solid lines). The early stages of cold acclimation were actually lost in early October, during a period of unusually warm temperatures when 
daily highs were near or exceeded $30{ }^{\circ} \mathrm{C}$ (Fig. 5 ); it took 3 to 4 weeks to return to a stage of cold-hardiness similar to that of mid-September. The hardiness of the apical and basal parts of the current year's shoot growth was compared to determine whether sampling position influenced cold acclimation values. For three of the five treatments (T1, T3, and T4), there were no significant differences $(\mathrm{a}=0.05)$

Table 4. Total nitrogen $(\mathrm{N})$ levels in dormant 'Ulster' sweet cherry flower spurs after leaf drop (12 Dec. 2007) after fall applications of urea (3.5\%) on 31 Aug. and 8 Sept. (T1), on 14 Sept. and 21 Sept. (T2), on 28 Sept. and 6 Oct. (T3), and on 12 Oct. and 20 Oct. (T4).

\begin{tabular}{lc}
\hline Treatments & Total $\mathrm{N}(\%)$ \\
\hline Control & $1.7 \mathrm{a}^{\mathrm{z}}$ \\
T1 & $2.2 \mathrm{~b}$ \\
T2 & $2.1 \mathrm{~b}$ \\
T3 & $1.7 \mathrm{a}$ \\
T4 & $1.6 \mathrm{a}$ \\
\hline${ }^{2}$ Assignment of the same letter indicates values that
\end{tabular}
are not significantly different. in the level of cold-hardiness resulting from position (data not shown; see Ouzounis, 2008). For the controls, and for T2, the basal shoot segments were significantly more hardy, by $\approx 2{ }^{\circ} \mathrm{C}$, than the apical segment. The data reported in Figures 4 and 5 are for the combined data sets.

Each foliar urea treatment was compared with the untreated control at $\approx 1$ week and 3.5 weeks after the second application for each treatment series (Fig. 4). At every treatment comparison date except the first comparison for T2, the urea-treated shoots were significantly more cold-hardy with $\mathrm{LT}_{50}$ values ranging from 1.0 to $4.25^{\circ} \mathrm{C}$ lower. The first T2 sampling occurred during the period of warmer temperatures in which highs were near or exceeded $30{ }^{\circ} \mathrm{C}$ (Fig. 5), and the difference between the control and the treatment was only $\approx 1{ }^{\circ} \mathrm{C}$. The greatest early cold acclimation occurred with the earliest urea applications (T1), and although the control shoots lost hardiness during the warm period in early October, the $\mathrm{T} 1$ shoots remained essentially unchanged (being $3{ }^{\circ} \mathrm{C}$ more hardy on 12

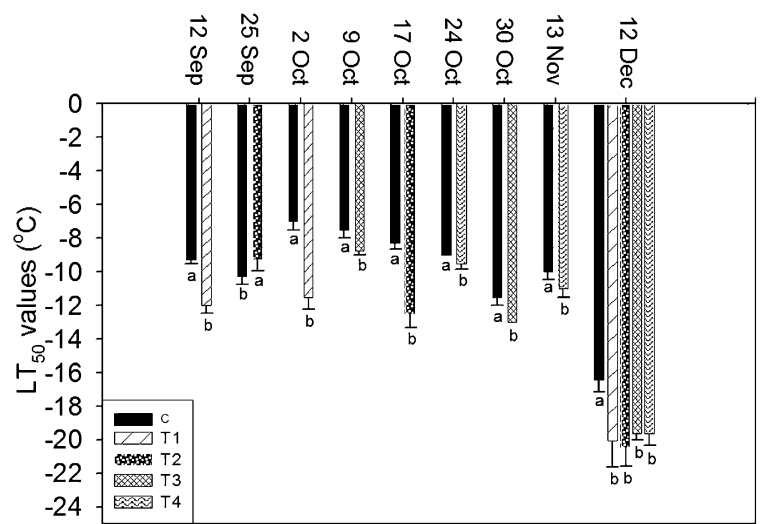

Fig. 4. Effect of fall foliar urea applications on $\mathrm{LT}_{50}$ values for 'Ulster'/Gi6 sweet cherry shoots during cold acclimation in fall and early Winter 2007. Foliar urea (3.5\%) was applied on 31 Aug. and 8 Sept. (T1), on 14 and 21 Sept. (T2), on 28 Sept. and 6 Oct. (T3), and on 12 and 20 Oct. (T4); C represents the untreated control. Error bars are SEs from the mean. The same letter following paired values [control and treatment(s)] for each sampling time indicates that they are not significantly different.

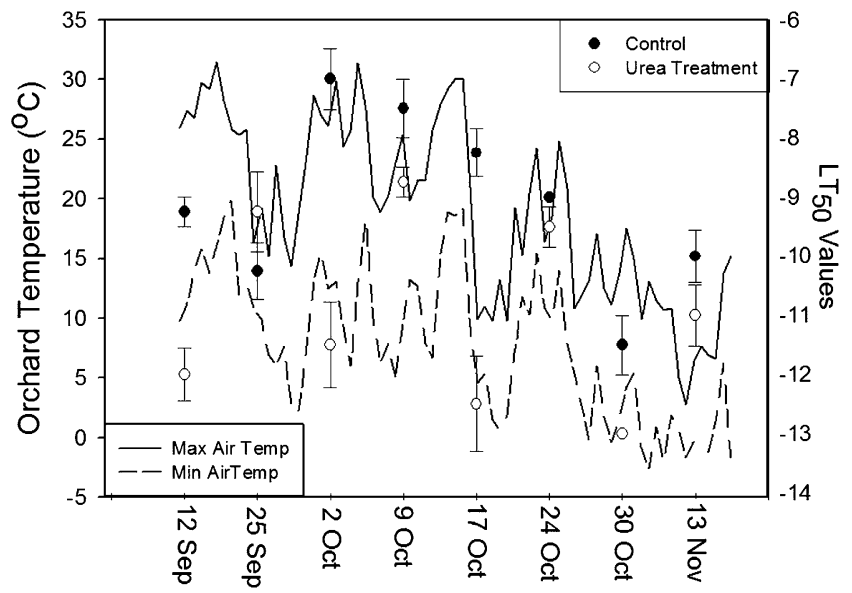

Fig. 5. Changes in air temperature and $\mathrm{LT}_{50}$ values for paired control and urea-treated shoot samples of 'Ulster'/Gi6 sweet cherry during cold acclimation in Fall 2007. Error bars are ses from the original mean data. T1 was sampled on 12 Sept. and 2 Oct., T2 on 25 Sept. and 17 Oct., T3 on 9 and 30 Oct., and T4 on 24 Oct. and 13 Nov.

Sept. and $5{ }^{\circ} \mathrm{C}$ more hardy on 2 Oct.). By early December, trees had defoliated completely and were endodormant. On $12 \mathrm{Dec}$., the $\mathrm{LT}_{50}$ values for all of the urea treatments were significantly lower $\left(\approx 4{ }^{\circ} \mathrm{C}\right)$ than the untreated controls (Fig. 4). By this time, there were no significant differences between the urea treatments.

\section{Discussion}

Nitrogen remobilization. Total $\mathrm{N}$ in leaves of 'Sandra Rose' and 'Rainier' sweet cherry trees on Gi5 dwarfing rootstocks decreased during senescence, whereas $\mathrm{N}$ in flower spurs increased. This translocation of $\mathrm{N}$ from leaves to storage tissues before leaf abscission is an important source of $\mathrm{N}$ for spring growth, just as if a $\mathrm{N}$ fertilizer were applied directly to flower spurs (as well as other tissues to which $\mathrm{N}$ may be remobilized from storage). This natural $\mathrm{N}$ enrichment of flower spurs in the fall suggested that orchard fertilization strategies to preferentially increase leaf $\mathrm{N}$ before or during senescence may increase storage $\mathrm{N}$ levels in key tissues for early spring growth without stimulating new episodic canopy growth activity in the fall. Indeed, no stimulation of new growth was observed from any of the various foliar urea applications and timings in the experiments reported here.

Although our initial experiments demonstrated an increase in flower spur $\mathrm{N}$ concentration between leaf drop and just before bloom, the question of whether $\mathrm{N}$ was actively remobilized throughout the winter period or just before budbreak was not addressed. Consequently, we sampled flower spurs from 'Hedelfinger'/Gi5 sweet cherry trees on a monthly basis during winter and found that, in the cold winters of the Great Lakes region, negligible remobilization to the spurs occurred from December to the end of March. Soon thereafter, the $\mathrm{N}$ concentration increased tremendously $(150 \%)$ in April during bud swell and budbreak. This also indicated that $\mathrm{N}$ is required in very high amounts during the early stages of spring growth in sweet cherries (Fig. 2) and that $\mathrm{N}$ remobilized from other storage sites within the tree is in high demand by reproductive meristems like flower spurs for both spur leaf development and bloom.

Some researchers have stated that foliar urea applications to stone fruits are ineffective (Peryea and Willemsen, 2000), although others (Johnson et al., 2001) clearly showed that foliar applications to peach trees during fall can increase the amount of $\mathrm{N}$ in storage tissues. The magnitude of $\mathrm{N}$ increase from foliar urea is likely to be influenced by the $\mathrm{N}$ status of the plant before application, as has been shown in apple (Cheng et al., 2002). In our study, fall foliar urea applications increased total $\mathrm{N}$ levels during early endodormancy by up to $40 \%$ in flower buds, $20 \%$ in the shoot tips, and $13 \%$ in the bark (Table 2). This indicates that flower buds and shoot tips are relatively strong sinks for remobilized $\mathrm{N}$ taken up from foliar urea sprays in sweet cherries. Bark tissue showed a big increase in total $\mathrm{N}$ content between fall and spring for 
all treatments. Total $\mathrm{N}$ concentration in the shoot tips also increased between fall and spring, although the smallest impact occurred with the higher rates of urea. Our results are in agreement with those of Guak et al. (2005) who applied foliar urea to sweet cherries in early fall. They measured $\mathrm{N}$ concentration on 5 Oct. after the applications $(0 \%, 2 \%, 4 \%$, and $6 \%$ ) on 25 Sept. and 2 Oct. They found that the $6 \%$ treatment most effectively increased the $\mathrm{N}$ concentration in flower buds (by $24 \%$ ). The $4 \%$ treatment was also effective, increasing the $\mathrm{N}$ concentration in flower buds by $12 \%$, whereas the $2 \%$ treatment increased $\mathrm{N}$ concentration by $9 \%$. In the 'Hedelfinger'/Gi5 study, flower spur $\mathrm{N}$ concentration increased between fall and early spring but rather variably across treatments. The treatment with the lowest $\mathrm{N}$ values, the defoliated trees, increased similarly, but the levels were still much lower than for any of the other treatments, indicating a long-lasting negative effect of defoliation that persisted at least until bud swell. The urea concentrations used in this study (3\% to $5 \%$ ) caused slight marginal leaf browning, presumably as a result of pooling of spray at the leaf margin where it became more concentrated during drying.

The defoliation and urea experiment found that total $\mathrm{N}$ storage levels in flower spurs in the fall affected sweet cherry spur leaf development in the spring (Table 3). Lower $\mathrm{N}$ levels can lead to smaller spur leaves, which are critical suppliers of photosynthetic carbon during fruit development (Ayala and Lang, 2008), and thus may be a negative factor in orchard management attempts to achieve balanced leaf-area-to-fruit ratios suitable for promoting good fruit size. Trees with the highest $\mathrm{N}$ levels developed larger spur leaves in the spring and leaf area per spur increased with foliar urea application. The number of leaves per spur was affected only slightly. Fruit size was smallest on the defoliated trees, but crop loads were too variable to obtain any statistically significant fruit size data across the urea treatment trees. It is logical that the earliest growth events of the spring such as spur leaf expansion might be directly affected by storage $\mathrm{N}$ levels, but later growth events such as final fruit size or total shoot length might be influenced by any number of other factors (fruit set, pruning, periodic environmental stresses, pest outbreaks, etc.) in their developmental cascade such that that straightforward relationships to storage $\mathrm{N}$ levels may be masked.

Dong et al. (2002) found that $\mathrm{N}$ from urea was converted to amino acids in leaves after foliar application in the fall to apple trees (Malus domestica Borkh.) with roots and bark being the main sinks for $\mathrm{N}$. They noted that only $35 \%$ of the $\mathrm{N}$ applied as urea was absorbed by leaves and $63.6 \%$ of absorbed $\mathrm{N}$ was translocated out of leaves. Tagliavini et al. (1997) found that pear (Pyrus communis L.) leaves absorbed $58 \%$ to $69 \%$ of the $\mathrm{N}$ applied as urea and concluded that more $\mathrm{N}$ derived from root uptake was used for remobilization in the spring than from foliar N. Rosecrance et al. (1998a, 1998b) found that $48 \%$ to $58 \%$ of foliar-applied urea was recovered in peach leaves and perennial organs, similar to the results of Tagliavini et al. (1997). When applied in September and October, most of the urea $\mathrm{N}(38 \%)$ was recovered in roots and when applied on November (before leaf senescence in California), $45 \%$ remained in the current-year wood. In our studies, we applied urea mainly in mid-October, just before leaf senescence in Michigan, because export and translocation of the foliar-applied urea $\mathrm{N}$ likely would have been reduced at the final stages of leaf senescence in early November.

These results do not imply that foliar applications of urea may provide adequate $\mathrm{N}$ for all phases of sweet cherry growth. When Johnson et al. (2001) applied only foliar urea to peach and no soil $\mathrm{N}$ across a full season, they found a significant reduction in weight per fruit and a tendency toward reduced tree yields compared with the soil applications. However, a combination of foliar urea in October and soil fertilization in summer maintained productivity and fruit weight compared with treatments with $\mathrm{N}$ applied only through the soil. Embleton et al. (1986) also suggested that the best practice in citrus (Citrus limon) may be a combination of foliar and soil applications of N. From an environmental perspective, Dong et al. (2004) reported that multiple foliar N applications can reduce the risk of nitrate leaching in apple orchards without reducing yield or fruit quality. Foliar fertilization can improve $\mathrm{N}$ use efficiency relative to soil-applied $\mathrm{N}$ and therefore can lead to reduced leaching of nitrates in the groundwater (Embleton et al., 1986). In sweet cherries, the potential to enhance storage $\mathrm{N}$ levels in key tissues like flower spurs, without stimulating late-season, succulent vegetative growth, may be a valuable use of such a foliar fertilization strategy. Like with most aspects of $\mathrm{N}$ fertilization, the impacts of supplemental foliar applications may be inversely proportional to the preapplication $\mathrm{N}$ status of the plant with greater effects on trees of lower $\mathrm{N}$ status and diminishing effects on trees of higher $\mathrm{N}$ status.

Cold acclimation. Andrews and Proebsting (1987) found a significant correlation in fall and winter between the previous night's minimum air temperature and $\mathrm{LT}_{50}$ values for sweet cherry flower buds. The shoot acclimation trends in our experiment likewise were influenced by periods of warm temperatures that interrupted, and briefly reversed, acclimation. The urea treatments generally had a positive effect on cold acclimation, suggesting that perhaps higher storage $\mathrm{N}$ levels or amino acid forms important for remobilization facilitate more rapid acclimation at moderate temperatures. The foliar urea treatments during early September not only did not stimulate any lateseason growth but were associated with the most rapid and long-lasting enhancement of cold-hardiness. This enhancement appeared to be less sensitive to the warm temperature events that coincided with the reversal of hardiness in the control trees, although new experiments with more extensive sampling would be needed to truly draw this conclusion.
Although our earlier (T1 and T2, September timing) urea treatments had the greatest enhancement of cold acclimation, the later treatments T3 (applied on 28 Sept. and 6 Oct.) and T4 (applied on 12 and 20 Oct.) only had a 1 to $2{ }^{\circ} \mathrm{C}$ lower $\mathrm{LT}_{50}$ than the controls in midfall. Guak et al. (2005) found no effect on cold-hardiness from repeat treatments in midfall (on 25 Sept. and 2 Oct.). We used 3.5\% urea and 9-year-old 'Ulster' sweet cherries on Gi6 rootstock, whereas Guak et al. used 2\%, $4 \%$, or $6 \%$ urea and 4-year-old 'Lapins' trees on seedling Mazzard rootstock. Although the midfall differences in cold-hardiness were relatively slight for our October treatments relative to the controls, by full endodormancy, all four urea treatments had $\mathrm{LT}_{50}$ values that were significantly lower (and equally more coldhardy) than the untreated control. Different climatic events for induction of cold acclimation, tree ages, varieties, rootstocks, locations, pre-application $\mathrm{N}$ status, and/or amount of urea may be responsible for the different reported impacts on cold-hardiness.

At this point of investigation, the potential mechanism for the effect of fall foliar $\mathrm{N}$ on cold-hardiness is not known; it may be speculated that this process involves a physiological interaction between suitable temperatures for induction of cold acclimation genes and specific amino forms of $\mathrm{N}$ synthesized in the leaves on uptake or as translocated to the localized sites of cold acclimation gene activity, but this or other appropriate hypotheses remain to be elucidated experimentally. Dong et al. (2005) showed that, in young apple trees, $\mathrm{N}$ taken up from soil applications in September remained primarily in the roots rather than being translocated to canopy tissues. Consequently, with respect to our results, it might be hypothesized that foliar urea applications in September advance both 1) the increase in canopy tissue $\mathrm{N}$ reserve levels as well as 2) concomitant processes like cold acclimation, which otherwise primarily occur later in fall on remobilization of $\mathrm{N}$ from leaves during senescence. Whether our reported effects on shoot cold-hardiness also extend to flower buds remains to be determined, although this hypothesis would predict similar effects because spur $\mathrm{N}$ levels increased rapidly in response to foliar urea.

\section{Conclusions}

Nitrogen remobilization from senescing leaves to storage tissues such as the flowering spurs is an important source of $\mathrm{N}$ for early spring growth in sweet cherry. Premature defoliation can negatively impact these reserves, whereas foliar applications of urea applied in the fall can increase storage $\mathrm{N}$ levels. The impact of these variations in fall $\mathrm{N}$ cycling is greater on flowering spurs compared with shoot apices or bark storage sites. Fall foliar urea applications increased sweet cherry spur leaf size and total leaf area per spur in spring, a positive management tool for increasing the leaf-to-fruit ratio in cherries grown on dwarfing and/or precocious rootstocks like Gi5 and Gi6, which are more prone to cropping heavily and 
having reduced $\mathrm{N}$ storage tissues than vigorous trees on seedling rootstocks like Mazzard or Prunus mahaleb.

Two foliar applications of urea in early September, $\approx 1$ week apart, were more effective at increasing total $\mathrm{N}$ in flowering spurs than applications in early to mid-October. Somewhat surprisingly, these applications also positively affected sweet cherry cold acclimation in fall. Shoots treated with urea were up to $4.25{ }^{\circ} \mathrm{C}$ more cold-hardy than untreated shoots both during early fall (October) and during early endodormancy (December). Periods of warm temperatures during fall reversed shoot cold acclimation in untreated trees, but to a lesser extent, if at all, in trees treated with urea. This impact of $\mathrm{N}$ reserve levels on coldhardiness of sweet cherries also should be examined during winter and spring to determine whether they might enhance resistance to incidents like extremely low temperatures during the midwinter and/or during early spring frosts. Further study of the physiology of $\mathrm{N}$ remobilization/metabolism and its potential relationship to cold acclimation in perennial fruit trees is warranted.

\section{Literature Cited}

Andersen, R.L., T. Robinson, and G.A. Lang. 1999. Managing the Gisela ${ }^{\circledR}$ cherry rootstocks. New York Fruit Quarterly 7:1-4.

Andrews, P.K. and E.L. Proebsting, Jr. 1987. Effects of temperature on the deep supercooling characteristics of dormant and deacclimating sweet cherry flower buds. J. Amer. Soc. Hort. Sci. 112:334-340.

AOAC Official Methods of Analysis. 1990. Protein (crude) in animal feed. Semiautomated method No. 976.06. p. 72.

Ayala, M. and G. Lang. 2004. Examining the influence of different leaf populations on sweet cherry fruit quality. Acta Hort. 636:481-488.

Ayala, M. and G.A. Lang. 2008. 13C-Photoassimilate partitioning in sweet cherry on dwarfing rootstocks during fruit development. Acta Hort. 795:625-632.

Bittenbender, H.C. and G.S. Howell, Jr. 1974. Adaptation of the Spearman-Karber method for estimating the $T_{50}$ of cold stressed flower buds. J. Amer. Soc. Hort. Sci. 99:187-190.

Bondada, B.R., J.P. Syvertsen, and L.G. Albrigo. 2001. Urea nitrogen uptake by citrus leaves. HortScience 36:1061-1065.

Bowman, D.C., J.L. Paul, and R.M. Carlson. 1988. A method to exclude nitrate from Kjeldahl digestion of plant tissues. Commun. Soil Sci. Plant Anal. 19:205-213.

Bradstreet, R.G. 1965. The Kjeldahl method for organic nitrogen. Academic Press, New York, NY, and London, UK.

Cheng, L., S. Dong, and L.H. Fuchigami. 2002. Urea uptake and nitrogen mobilization by apple leaves in relation to tree nitrogen status in autumn. J. Hortic. Sci. Biotechnol. 77:13-18.

Cope, W.C. 1916. Kjeldahl modification for determination of nitrogen in nitro substitution compounds. J. Ind. Eng. Chem. 8:592-593.

Dong, S., L. Cheng, C.F. Scagel, and L.H. Fuchigami. 2002. Nitrogen absorption, translocation and distribution from urea applied in autumn to leaves of young potted apple (Malus domestica) trees. Tree Physiol. 22:1305-1310.

Dong, S., L. Cheng, C.F. Scagel, and L.H. Fuchigami. 2004. Nitrogen mobilization, nitrogen uptake and growth of cuttings obtained from poplar stock plants grown in different $\mathrm{N}$ regimes and sprayed with urea in autumn. Tree Physiol. 24:355-359.

Dong, S., L. Cheng, C.F. Scagel, and L.H. Fuchigami. 2005. Nitrogen absorption, translocation and distribution from urea applied in autumn to leaves of young potted apple (Malus domestica) trees. J. Hort. Sci. Biotechnol. 80: 116-120.

Embleton, T.W., M. Matsumura, L.H. Stolzy, D.A Devitt, W.W. Jones, R. El-Motaium, and L.L. Summers. 1986. Citrus nitrogen fertilizer management, groundwater pollution, soil salinity and nitrogen balance. Appl. Agr. Res. 1:57-64.

Guak, S., M. Beulah, D. Neilsen, H.A. Quamme, and N.E. Looney. 2005. Effects of urea and plant bioregulators (Ethephon and Promalin) on tissue nitrogen levels, cold hardiness, and cropping of sweet cherry trees. Acta Hort. 667:453-460.

Howell, G.S. and C.J. Weiser. 1970. Fluctuation in the cold hardiness of apple twigs during spring dehardening. J. Amer. Soc. Hort. Sci. 95:190-192.

Johnson, R.S., R. Rosecrance, S. Weinbaum, H. Andris, and J. Wang. 2001. Can we approach complete dependence on foliar-applied urea nitrogen in an early-maturing peach? J. Amer. Soc. Hort. Sci. 126:364-370.

Keller, J.D. and W.H. Loescher. 1989. Nonstructural carbohydrate partitioning in perennial parts of sweet cherry. J. Amer. Soc. Hort. Sci. 114:969-975.

Lang, G.A. 2000. Precocious, dwarfing, and productive-How will new cherry rootstocks impact the sweet cherry industry? HortTechnology 10:719-725.

McCammant, T. 1988. Utilization and transport of storage carbohydrates in sweet cherry. MS thesis, Washington State University, Pullman, WA.
McKenzie, J.S. and C.J. Weiser. 1975. Technique to inoculate woody plant stem sections with ice during artificial freezing. Can. J. Plant Sci. 55:651-653.

Millard, P. 1996. Ecophysiology of the internal cycling of nitrogen for tree growth. Z. Pflanzen. Boden 159:1-10.

Neilsen, D., P. Millard, G.H. Neilsen, and E.J. Hogue. 1997. Sources of $\mathrm{N}$ for leaf growth in a high-density apple (Malus domestica) orchard irrigated with ammonium nitrate solution. Tree Physiol. 17:733-739.

Ouzounis, T. 2008. Storage nitrogen manipulations in sweet cherry (Prunus avium L.) on dwarfing rootstocks. MSc thesis, Michigan State University, East Lansing, MI

Peryea, F. and K. Willemsen. 2000. Nutrient sprays. Washington State University, Tree Fruit Research \& Extension Center. <http://www.tfrec.wsu.edu/ Horticulture/nutspray.html\#CuPost>.

Raese, T.J. 1996. Calcium nutrition affects cold hardiness, yield, and fruit disorders of apple and pear trees. J. Plant Nutr. 19:1131-1155.

Rosecrance, R.C., R.S. Johnson, and S.A. Weinbaum. 1998a. Foliar uptake of urea-N by nectarine leaves: A reassessment. HortScience 33:158.

Rosecrance, R.C., R.S. Johnson, and S.A. Weinbaum. 1998b. The effect of timing of post-harvest foliar urea sprays on nitrogen absorption and partitioning in peach and nectarine trees. J. Hort. Sci. Biotechnol. 73:856-861.

Stover, E., M. Fargione, R. Risio, W. Stiles, and K. Iungerman. 1999. Prebloom foliar boron, zinc, and urea applications enhance cropping of some 'Empire' and 'McIntosh' apple orchards in New York. HortScience 34:210-214.

Tagliavini, M., M. Quartieri, and P. Millard. 1997. Remobilized nitrogen and root uptake of nitrate for spring leaf growth, flowers and developing fruits of pear (Pyrus communis L.) trees. Plant Soil 195:137-142.

Titus, J.S. and S. Kang. 1982. Nitrogen metabolism, translocation, and recycling in apple trees. Hort. Rev. 4:204-246.

Whiting, M.D. and G.A. Lang. 2004. 'Bing' sweet cherry on the dwarfing rootstock Gisela 5: I. Crop load effects on fruit quality, vegetative growth, and carbon assimilation. J. Amer. Soc. Hort. Sci. 129:407-415.

Yamada, Y., S.H. Wittwer, and M.J. Bukovac. 1965. Penetration of organic compounds through isolated cuticular membranes with special reference to ${ }^{14} \mathrm{C}$ urea. Plant Physiol. 40:170175.

Zavalloni, C. 2004. Evaluation of nitrogen-fertilizer uptake, nitrogen-use and water-use efficiency in sweet cherry (Prunus avium L.) on dwarfing and standard rootstocks. PhD diss., Michigan State University, East Lansing, MI. 